\title{
Key locations for soybean genotype assessment in Central Brazil
}

\author{
Roberto Miranda Pacheco(1), João Batista Duarte(1),Plínio Itamar Mello de Souza ${ }^{(2)}$, \\ Sérgio Abud da Silva( ${ }^{(2)}$ and José Nunes Junior ${ }^{(3)}$
}

(1)Universidade Federal de Goiás, Escola de Agronomia e Engenharia de Alimentos, Setor de Melhoramento de Plantas, Caixa Postal 131, CEP 74001-970 Goiânia, GO, Brazil. E-mail: robertopacheco21@uol.com.br, jbduarte@agro.ufg.br (2)Embrapa Cerrados, Caixa Postal 08223, CEP 73310-970 Planaltina, DF, Brazil. E-mail: plinio@cpac.embrapa.br, abud@cpac.embrapa.br ${ }^{(3)}$ Centro Tecnológico para Pesquisas Agropecuárias, Rodovia BR 153, Km 4, Zona Rural, CEP 74001-970 Goiânia, GO, Brazil. E-mail: nunes@ctpa.com.br

Abstract - The objective of this work was to identify key locations for the establishment of soybean (Glycine max) genetic breeding programs, in the Central Region of Brazil. Grain yield data of three maturity groups of soybean genotypes, from regional trials conducted over three years, at 18 locations in Brazilian Cerrado were used. A key location for the early phases of the breeding program was defined as the site that best classifies the winning genotypes in the region. Key locations for the final phases were defined as those sites that best represent each environmental stratum, in relation to the adaptability of the respective winning genotype. This adaptability was estimated by additive main effects and multiplicative interaction (AMMI) model analysis, using the distance between the score of each location in a stratum and the score of the winning genotype, which characterizes such stratum in an AMMI biplot. The locations that best classified the winning genotypes over space and time were Mineiros, Placas and Rio Verde. For the final phases of genotype selection, with data from the three maturity group, the recommended locations were: Buritis, Chapadão do Céu, Iraí, Pamplona, Placas, Planaltina, Rio Verde, Sacramento, Senador Canedo, Uberaba, and Uberlândia.

Index terms: Glycine max, adaptability, AMMI analysis, environmental stratification, G×E interaction.

\section{Locais-chave para avaliação de genótipos de soja na Região Central do Brasil}

\begin{abstract}
Resumo - O objetivo deste trabalho foi identificar locais-chave para o estabelecimento de programas de melhoramento genético de soja (Glycine max), na Região Central do Brasil. Foram utilizados dados de produtividade de grãos de genótipos de soja, de três ciclos de maturação, obtidos de ensaios regionais conduzidos por três anos em 18 localidades da região. O local-chave para a condução das fases preliminares do programa foi definido como a localidade que melhor classifica os genótipos vencedores na região. Os locais-chave para as fases finais foram definidos como os que melhor representam cada estrato ambiental identificado, em termos da adaptabilidade do respectivo genótipo vencedor. Essa adaptabilidade foi estimada por meio do modelo de efeitos principais aditivos e interação multiplicativa (AMMI), tendo-se utilizado a distância entre os pontos (escores) correspondentes a cada local em um estrato e o escore do genótipo vencedor que caracteriza aquele estrato, em um "biplot" AMMI. Os locais que melhor classificaram os genótipos vencedores ao longo do espaço e do tempo foram: Mineiros, Placas e Rio Verde. Para as fases finais de seleção de genótipos, com os dados dos três ciclos de maturação, os locais recomendados foram: Buritis, Chapadão do Céu, Iraí, Pamplona, Placas, Planaltina, Rio Verde, Sacramento, Senador Canedo, Uberaba e Uberlândia.
\end{abstract}

Termos para indexação: Glycine max, adaptabilidade, análise AMMI, estratificação ambiental, interação G×E.

\section{Introduction}

Intensive management techniques for soybean (Glycine max L.) crop, allied to genetic breeding, have resulted in expressive increases in grain productivity. With the genetic breeding progress, research activities have become more expensive, requiring greater care and technical refinement. It is, therefore, important to critically assess genotypes as for the environments targeted by the research. Thus, in the process of developing genetic materials adapted to a region, an aspect that has drawn the attention of researchers is the genotype $x$ environment (GE) interaction. The presence of this interaction is characterized by the alteration in

Pesq. agropec. bras., Brasília, v.44, n.5, p.478-486, maio 2009 
the phenotypic variance of a set of genotypes submitted to different environmental conditions, or by the lack of correlation among genotype responses in the series of environments. The occurrence of this phenomenon can lead to overestimations of the heritability value, because the GE interaction inflates the genotypic variance estimates with constant overvalue of the predicted gain with selection. It can also result in productivity reduction of a region for which a general recommendation of a given cultivar is made.

Germplasm evaluations for advancement in crop breeding programs, such as advanced soybean line experiments, are commonly carried out in several locations, under heterogeneous environmental conditions and with a large number of genotypes. Some evaluations have shown that the subdivision of production areas into megaenvironments is not justified, as reported in studies with peanuts by Casanoves et al. (2005) and Putto et al. (2008), respectively for Argentina and Thailand. Studies like those conducted by Dehghani et al. (2006) and Roozeboom et al. (2008), however, confirmed the effectiveness of the proposed subdivision for reducing GE interaction.

The production optimization in a region, where significant GE interaction has been identified, is related to the possibility that this region can be divided into relatively homogeneous zones, and that the best performing genotypes in each one can be designated to them. These homogeneous zones or subregions, also called as agroecological zones, are equivalent to a regionalization that has been more widely called megaenvironment (International Maize and Wheat Improvement Center, 1989). According to this concept, a megaenvironment consists of large areas, not necessarily continuous, usually international and frequently transcontinental, defined by being similar in terms of biotic and abiotic stress, crop system, consumer preferences etc.

Without subdivision into zones, only a cultivar of wide adaptation can be recommended, but with the environmental stratification, the specific adaptations of genotypes can also be exploited. In this sense, Gauch Junior \& Zobel (1997) argued that although the stratification of a crop region may imply a greater volume of work for breeders and seed producers, it results in higher heredities and, therefore, faster genetic progress in the target area of the breeding programs. Furthermore, it leads to greater competitive capacity among the seed producers and higher yields for the farmers.

Another important aspect comes up when homogeneous locations are identified in a region, because they can be redundant for the genetic breeding program. Thus, the choice of only one of these locations for genotype testing will increase the efficiency of the program. This kind of study characterizes the definition of key locations, and consists of choosing a local representative for each homogeneous subregion identified in the environments under evaluation. Crossa (1990) and Gauch Junior \& Zobel (1997) indicated AMMI analysis as a helpful statistical tool to identify highly productive and widely adapted genotypes, as well as to identify key locations to carry out selection in plant breeding programs. Other statistical analyses, based on singular value decomposition (SVD), have been proposed, such as the genotype main effects and genotype $\times$ environment interaction (GGE) model (Yan et al., 2000, 2007; Yan \& Tinker, 2005). These papers describe some advantages of the GGE biplot model compared to AMMI biplot. Nevertheless, recent review articles reinforce the recommendation to use the AMMI model (Gauch Junior, 2006; Gauch Junior et al., 2008).

Brazil is the second largest world producer of soybean (exceeded only by the United States) with almost 60 million tons of this grain (IBGE, 2009). About $60 \%$ of this production comes from the Cerrado region, where about 12 million ha of soybean are grown, with an average yield of nearly $3 \mathrm{Mg} \mathrm{ha}^{-1}$ (higher than the national average $-2.8 \mathrm{Mg} \mathrm{ha}^{-1}$ ). Despite this national and international importance, comprehensive studies of environmental stratification, based on GE interaction in soybean, have not yet been developed for this region.

The objective of this work was to identify key locations to carry out a soybean genetic breeding program for the Central Region of Brazil, with emphasis in the phases of preliminary line assessment and final cultivar recommendation.

\section{Materials and Methods}

Grain yield data from regional trials for soybean line assessment in three agricultural seasons (1999/2000, 2000/2001 and 2001/2002) were used. The lines of early, medium and late maturity groups (cycles) were, in part, replaced for new ones from one year to another. This is 
a positive aspect for inference purposes of this study, because the soybean germplasm cropped in the target region was better represented. The complete data used were presented by Pacheco (2004). The experiments were carried out in 18 locations in the Central Region of Brazil, also called Cerrado region, in the states of Goiás, Mato Grosso, Bahia, and Minas Gerais and in the Federal District (Table 1). A randomized complete block design was used in each trial, with four replicates. The treatments consisted of test lines and cultivars of soybean, whose number ranged from 23 to 28 , depending on the growing year and maturity group. The plots consisted of four $5 \mathrm{~m}$ rows spaced at $0.5 \mathrm{~m}$, and the two central rows were considered as the useful plot area, discarding $0.5 \mathrm{~m}$ from each end.

To define the key locations in the trial network, the most representative ones of each stratum were sought based on the environmental clustering obtained by Pacheco (2004). The stratification performed by Pacheco (2004) was done according to the AMMI analysis of GE interaction (Zobel et al., 1988; Duarte \& Vencovsky, 1999), associated to the winning genotype approach proposed by Gauch Junior (1992) and Gauch Junior \& Zobel (1997). In this approach, a winning genotype was the one that attains the highest

Table 1. Brazilian locations and their geographic coordinates, where the variety trials of soybean test lines and cultivars were carried out in this study ${ }^{(1)}$.

\begin{tabular}{lccr}
\hline Location & $\begin{array}{c}\text { Latitude } \\
\text { South }\end{array}$ & $\begin{array}{c}\text { Longitude } \\
\text { West }\end{array}$ & $\begin{array}{r}\text { Altitude } \\
(\mathrm{m})\end{array}$ \\
\hline Anápolis, GO & $16^{\circ} 27^{\prime}$ & $48^{\circ} 57^{\prime}$ & 1,017 \\
Chapadão do Céu, GO & $18^{\circ} 32^{\prime}$ & $52^{\circ} 32^{\prime}$ & 800 \\
Cristalina, GO & $16^{\circ} 50^{\prime}$ & $47^{\circ} 36^{\prime}$ & 930 \\
Luziânia, GO & $16^{\circ} 16^{\prime}$ & $47^{\circ} 57^{\prime}$ & 930 \\
Mineiros, GO & $17^{\circ} 34^{\prime}$ & $52^{\circ} 33^{\prime}$ & 980 \\
Rio Verde, GO & $17^{\circ} 41^{\prime}$ & $50^{\circ} 55^{\prime}$ & 730 \\
Senador Canedo, GO & $16^{\circ} 33^{\prime}$ & $49^{\circ} 05^{\prime}$ & 801 \\
Correntina, BA & $13^{\circ} 33^{\prime}$ & $44^{\circ} 38^{\prime}$ & 950 \\
Placas, BA & $11^{\circ} 08^{\prime}$ & $47^{\circ} 38^{\prime}$ & 780 \\
Pamplona, DF & $16^{\circ} 05^{\prime}$ & $47^{\circ} 30^{\prime}$ & 1,008 \\
Planaltina, DF & $15^{\circ} 31^{\prime}$ & $47^{\circ} 36^{\prime}$ & 1,003 \\
Buritis, MG & $15^{\circ} 27^{\prime}$ & $46^{\circ} 25^{\prime}$ & 900 \\
Capinópolis, MG & $18^{\circ} 41^{\prime}$ & $49^{\circ} 34^{\prime}$ & 950 \\
Conquista, MG ${ }^{(2)}$ & $19^{\circ} 52^{\prime}$ & $47^{\circ} 32^{\prime}$ & 830 \\
Iraí de Minas, MG & $18^{\circ} 57^{\prime}$ & $47^{\circ} 27^{\prime}$ & 975 \\
Sacramento, MG & $19^{\circ} 51^{\prime}$ & $47^{\circ} 26^{\prime}$ & 1,038 \\
Uberaba, MG ${ }^{(3)}$ & $19^{\circ} 42^{\prime}$ & $47^{\circ} 55^{\prime}$ & 781 \\
Uberlândia, MG & $19^{\circ} 05^{\prime}$ & $48^{\circ} 16^{\prime}$ & 1,012 \\
Lucas do Rio Verde, MT & $13^{\circ} 09^{\prime}$ & $55^{\circ} 54^{\prime}$ & 350 \\
\hline (1)Latitude and longitude data were provided by Embrapa Cerrados and \\
refer to the trial location, while altitude data were provided by IBGE (2008) \\
and refer to the headquarters of the closest municipality. ${ }^{(2)}$ Only for late \\
maturity group. ${ }^{(3)}$ Not for late maturity group. & &
\end{tabular}

Pesq. agropec. bras., Brasília, v.44, n.5, p.478-486, maio 2009 yield in a given environment. These genotypes have, therefore, the best specific adaptation to the stratum that they determine, as well as agronomic stability for the locations that make up this stratum.

The key locations for the final phases of the breeding program were defined as those that should be primarily chosen in each stratum for the genotypic assessment and selection steps, whose main purpose is to provide cultivars for the region represented by such locations. The coordinates (scores) of environments and genotypes were displayed in a graphic representation called biplot (Gabriel, 1971, 1978). These scores were estimated by AMMI analysis, specifically from setting the AMMI1 model, that is, with only one interaction axis, named IPCA1. Then, for each identified stratum, the Euclidean average distances between the graphic points related to the stratum locations and its winning genotype were obtained. The location with the lowest average distance to the winning genotype over the years was chosen preliminary as the key location for that stratum.

The indication of a key location to carry out the initial phases of the selective process (eg. generation advance) was established by ranking winning genotypes in all locations of the trial network. Thus, a key location for these phases was defined as the one that best classified the winning genotypes, over the years, i.e., the location that minimizes the probability of discarding winning genotypes in the target region. For the identification of the key location, the mean of the yield ranks of these genotypes in each location, weighted by the numbers of their wins, taking account all the locations, was used. In order to prevent the definition of a key location only for the initial phases of the selection process, this site was chosen among those previously defined as key locations to carry out the final selection phases.

\section{Results and Discussion}

\section{Location for genotype tests in the final selection phases}

The environmental stratification into homogeneous groups leads to the need for identification of key locations within these groups, where the genotype tests should be prioritized in the selection phases of the plant breeding programs.

The strata and the distances $\left(d_{\mathrm{vj}}^{2}\right)$ between each location (j) and the winning genotype (v) within each stratum and growing year are shown in Tables 2, 3, and 4 
(early, medium and late maturity groups, respectively). These tables also show the means of these distances in the three growing years $\left(\overline{\mathrm{d}}_{\mathrm{vj}}^{2}\right)$, for each test location. Examination of these results allows the identification of the key location, for the final phases of the genotypic assessment related to the target populations of the genotypes and environments.

The results for the early maturity group (Table 2 ) show that in the first three environmental clusters obtained, Buritis, Luziânia, and Pamplona were the locations that most geometrically approached the winning genotype that characterized their respective strata. It was further observed that in growing year 2000, Buritis was the third location closest to the winning genotype in the first cluster, and showed a small distance to this genotype in 2001, as well as the second shortest distance in 2002. In the second cluster, Luziânia was the closest location to the respective winning genotype, in 2000 and 2002, and was ranked as third (very close to the second) in 2001. In the other cluster, Pamplona was geometrically the nearest from the winning genotypes in 2000 and 2001, and was ranked as the second closest location in 2002. Based on these results, eight key locations were chosen for the final stages of early maturity group genotype assessment: Buritis, Luziânia, and Pamplona, reported previously, and Iraí, Chapadão do Céu, Uberaba, Planaltina, and Senador Canedo, that should also be indicated because they did not group with other locations.

For the medium maturity group genotypes (Table 3), also in the first three environmental clusters obtained, it was observed that the locations Buritis, Anápolis, and Pamplona showed the smallest mean Euclidean distances, in relation to the winning genotypes that characterized each of these clusters. It was further verified that, in the growing year 2000, these locations were ranked at second place regarding their distances to the respective winner genotype, and were basically the closest in the other years, except for Anápolis, in 2001, that was also in second place, but very close to

Table 2. Environmental strata and winning genotypes with their GE interaction scores (IPCA1), estimated by AMMI analysis, and the quadratic distances $\left(\mathrm{D}^{2}\right)$ between each location and the winning genotype of the respective stratum, for the early maturity group of soybean genotypes, in three assessment years ${ }^{(1)}$.

\begin{tabular}{|c|c|c|c|c|c|c|c|}
\hline \multirow[t]{2}{*}{ Environmental strata } & \multicolumn{2}{|c|}{2000} & \multicolumn{2}{|c|}{2001} & \multicolumn{2}{|c|}{2002} & \multirow[t]{2}{*}{$\overline{\mathrm{D}}^{2(2)}$} \\
\hline & IPCA1 & $\mathrm{D}^{2}$ & IPCA1 & $\mathrm{D}^{2}$ & IPCA1 & $\mathrm{D}^{2}$ & \\
\hline Buritis, MG & -5.68 & 31.69 & -7.38 & 0.05 & -13.53 & 5.06 & 12.27 \\
\hline Lucas do Rio Verde, MT & -9.73 & 93.69 & 1.15 & 74.64 & -15.97 & 0.04 & 56.82 \\
\hline Capinópolis, MG & 8.43 & 71.92 & -14.98 & 54.32 & -6.58 & 84.64 & 70.29 \\
\hline Rio Verde, GO & -3.14 & 9.55 & 2.79 & 108.16 & -6.11 & 93.51 & 70.40 \\
\hline Correntina, BA & -2.37 & 5.38 & -15.56 & 63.20 & -27.80 & 144.48 & 71.02 \\
\hline Winning genotypes & \multicolumn{2}{|c|}{ BR89-10744 CE; IPCA1 = -0.05 } & \multicolumn{2}{|c|}{ MG/BR95-964; IPCA1 = -7.61 } & \multicolumn{2}{|c|}{ Apiakas; IPCA1 $=-15.78$} & \\
\hline Luziânia, GO & 0.48 & 0.28 & 3.38 & 120.78 & 10.96 & 1.85 & 40.97 \\
\hline Placas, BA & -6.14 & 37.08 & 3.31 & 119.25 & 4.37 & 27.35 & 61.23 \\
\hline Mineiros, GO & -5.71 & 32.03 & 4.68 & 151.04 & 7.76 & 3.39 & 62.15 \\
\hline Cristalina, GO & 5.55 & 31.36 & -4.46 & 9.92 & -4.13 & 188.51 & 76.60 \\
\hline Sacramento, MG & 6.38 & 41.35 & 8.07 & 245.86 & 13.42 & 14.59 & 100.60 \\
\hline Winning genotypes & \multicolumn{2}{|c|}{ BR89-10744 CE; IPCA1 $=-0.05$} & \multicolumn{2}{|c|}{ MG/BR95-964; IPCA1 = -7.61 } & \multicolumn{2}{|c|}{ MGBR97-2545; IPCA1 = 9.6C } & \\
\hline Pamplona, DF & 10.66 & 23.08 & -0.01 & 57.76 & 4.81 & 22.94 & 34.59 \\
\hline Anápolis, GO & 16.07 & 104.33 & 6.20 & 190.72 & 7.97 & 2.66 & 99.23 \\
\hline Uberlândia, MG & 13.47 & 57.97 & 3.63 & 126.34 & 30.16 & 422.71 & 203.34 \\
\hline Winning genotypes & \multicolumn{2}{|c|}{ BR95-15305 CE; IPCA1 = 5.86} & \multicolumn{2}{|c|}{ MG/BR95-964; IPCA1 = -7.61 } & \multicolumn{2}{|c|}{ MGBR97-2545; IPCA1 = 9.60} & \\
\hline Iraí de Minas, MG & -21.12 & - & 30.95 & - & 30.90 & - & - \\
\hline Winning genotypes & \multicolumn{2}{|c|}{ BR96-019431 MG } & \multicolumn{2}{|c|}{ BRAS97-8091 } & \multicolumn{2}{|c|}{ MGBR97-2545 } & \\
\hline Chapadão do Céu, GO & -9.61 & - & 11.58 & - & -9.05 & - & - \\
\hline Winning genotypes & \multicolumn{2}{|c|}{ BR89-10744 CE } & \multicolumn{2}{|c|}{ BRAS97-8091 } & \multicolumn{2}{|c|}{ Apiakas } & \\
\hline Uberaba, MG & -21.00 & - & -0.04 & - & -7.86 & - & - \\
\hline Winning genotypes & \multicolumn{2}{|c|}{ BR96-019431 MG } & \multicolumn{2}{|c|}{ MGBR95-964 } & \multicolumn{2}{|c|}{ GOBR96-014101 } & \\
\hline Planaltina, GO & 26.07 & - & -2.17 & - & -24.17 & - & - \\
\hline Winning genotypes & \multicolumn{2}{|c|}{ G: BR95-7783 CE } & \multicolumn{2}{|c|}{ G: MGBR95-964 } & \multicolumn{2}{|c|}{ Apiakas } & \\
\hline Senador Canedo, GO & -2.61 & - & -30.78 & - & 4.86 & - & - \\
\hline Winning genotypes & \multicolumn{2}{|c|}{ BR89-10744 CE } & \multicolumn{2}{|c|}{ FT-2000 } & \multicolumn{2}{|c|}{ MGBR97-2545 } & \\
\hline
\end{tabular}

${ }^{(1)}$ Environment stratification was performed by Pacheco (2004), according to AMMI analysis of GE interaction (Zobel et al., 1988; Duarte \& Vencovsky, 1999), associated to the winning genotype approach proposed by Gauch Junior (1992) and Gauch Junior \& Zobel (1997). ${ }^{(2)} \overline{\mathrm{D}}^{2}$ is the mean quadratic distance through the years. 
Sacramento, that showed the smallest mean distance to the respective winning genotype. In addition, it was verified that the locations closer to the winning genotype in 2000, Planaltina, Capinópolis, and Mineiros, in these three clusters, were fairly apart from this genotype kind in the following years, so they should not be indicated. The same fact occurred with Sacramento location, in the years in which it was not the geometrically closest location to the winning genotype (2000 and 2002). Thus, for the final assessment phases of the medium maturity group genotypes, six locations were chosen: Buritis, Anápolis, and Pamplona, reported previously, and Iraí, Chapadão do Céu, and Uberlândia, which did not group to other locations and showed to be environments with peculiar characteristics in the target region.

For the late maturity group (Table 4), in the first four environmental clusters identified, the IPCA1 scores of the locations Rio Verde, Buritis, Placas, and Pamplona showed the smallest mean distances in relation to the respective winning genotypes. Although Rio Verde was not the location geometrically closest to the winning genotype in any of the years, this site maintained a small distance in relation to the winners in the three years considered, and was, therefore, chosen. The locations that were the closest to the winning genotype in this cluster, in each year (Senador Canedo in 2000, and Mineiros in 2001 and 2002), showed great distancing at least in one year, increasing the mean distances related to the winning genotype. In the second cluster, with only two locations, Buritis was the closest one to the winners in two years (2000 and 2002); and in the third cluster, Placas was also the closest location to the respective winning genotype in two years (2000 and 2001). In the last cluster, also composed by only two locations, Pamplona was practically tied with Planaltina, in 2000, and geometrically much closer to the winner in 2001. Thus, for the final assessment phases of the late maturity group genotypes, seven key locations were chosen: Rio Verde, Buritis, Placas, and Pamplona, plus the locations Sacramento, Iraí, and Uberaba, because they did not group to other locations.

Finally, attempts were made to identify, among the key locations chosen for each maturity group, those

Table 3. Environmental strata and winning genotypes with their GE interaction scores (IPCA1), estimated by AMMI analysis, and the quadratic distances $\left(\mathrm{D}^{2}\right)$ between each location and the winning genotype of the respective stratum, for the medium maturity group of soybean genotypes, in three assessment years(1).

\begin{tabular}{|c|c|c|c|c|c|c|c|}
\hline \multirow[t]{2}{*}{ Environmental strata } & \multicolumn{2}{|c|}{2000} & \multicolumn{2}{|c|}{2001} & \multicolumn{2}{|c|}{2002} & \multirow[t]{2}{*}{$\overline{\mathrm{D}}^{2(2)}$} \\
\hline & IPCA1 & $\mathrm{D}^{2}$ & IPCA1 & $\mathrm{D}^{2}$ & IPCA1 & $\mathrm{D}^{2}$ & \\
\hline Buritis, MG & -17.11 & 13.81 & 26.72 & 12.82 & -9.95 & 2.92 & 9.85 \\
\hline Cristalina, GO & -5.78 & 57.98 & 14.95 & 67.08 & -3.06 & 26.83 & 50.63 \\
\hline Correntina, BA & -7.65 & 33.00 & 30.22 & 50.13 & -18.69 & 109.20 & 64.11 \\
\hline Planaltina, DF & -11.6 & 3.22 & 11.56 & 134.10 & -16.32 & 65.29 & 67.53 \\
\hline Placas, BA & -3.12 & 105.56 & 2.24 & 436.81 & -0.40 & 61.47 & 201.28 \\
\hline Rio Verde, GO & 7.17 & 422.56 & 0.64 & 506.25 & -2.47 & 33.29 & 320.81 \\
\hline Uberaba, MG & 1.19 & 212.70 & -7.01 & 909.02 & -21.26 & 169.52 & 430.41 \\
\hline Lucas do Rio Verde, MT & 2.13 & 241.00 & -8.77 & 1018.25 & -16.51 & 68.39 & 442.55 \\
\hline Winning genotypes & \multicolumn{2}{|c|}{ BR92-2658 CE; IPCA1 $=-13.39$} & \multicolumn{2}{|c|}{ BRAS97-0009; IPCA1 $=23.14$} & \multicolumn{2}{|c|}{ MSOY-8411; IPCA1 = -8.24 } & - \\
\hline Anápolis, GO & -7.75 & 31.86 & -22.81 & 7.29 & 9.49 & 3.17 & 14.11 \\
\hline Senador Canedo, GO & -2.72 & 113.94 & -13.86 & 147.62 & 6.72 & 20.70 & 94.09 \\
\hline Capinópolis, MG & -9.94 & 11.93 & -11.89 & 185.50 & -2.55 & 190.99 & 129.48 \\
\hline Sacramento, MG & 0.94 & 205.47 & -22.98 & 6.40 & -2.26 & 183.06 & 131.64 \\
\hline Winning genotypes & \multicolumn{2}{|c|}{ BR92-2658 CE; IPCA1 = -13.39 } & \multicolumn{2}{|c|}{ BR97-09894; IPCA1 = -25.51 } & \multicolumn{2}{|c|}{ BRA97-6705; IPCA1 = 11.27} & - \\
\hline Pamplona, DF & -4.42 & 80.54 & 10.09 & 170.30 & 11.97 & 0.49 & 83.78 \\
\hline Luziânia, GO & -1.67 & 137.46 & 6.34 & 282.24 & 15.07 & 14.44 & 144.71 \\
\hline Mineiros, GO & -7.94 & 29.75 & -4.83 & 782.32 & 5.30 & 35.64 & 282.57 \\
\hline Winning genotypes & \multicolumn{2}{|c|}{ BR92-2658 CE; IPCA1 $=-13.39$} & \multicolumn{2}{|c|}{ BRAS97-0009; IPCA1 $=23.14$} & \multicolumn{2}{|c|}{ BRA97-6705; IPCA1 = 11.27} & - \\
\hline Iraí de Minas, MG & 50.57 & - & -22.25 & - & 19.93 & - & - \\
\hline Winning genotypes & \multicolumn{2}{|c|}{ BR96-016119 } & \multicolumn{2}{|c|}{ BR97-09894 } & \multicolumn{2}{|c|}{ GOBR97-11587 } & - \\
\hline Chapadão do Céu, GO & 26.44 & - & 23.53 & - & -11.69 & - & - \\
\hline Winning genotypes & \multicolumn{2}{|c|}{ BR96-013721 } & \multicolumn{2}{|c|}{ BRAS97-0009 } & \multicolumn{2}{|c|}{ MSOY-8411 } & - \\
\hline Uberlândia, MG & 7.99 & - & -12.39 & - & 36.68 & - & - \\
\hline Winning genotypes & \multicolumn{2}{|c|}{ BR96-013721 } & \multicolumn{2}{|c|}{ Conquista } & \multicolumn{2}{|c|}{ GOBR97-11587 } & - \\
\hline
\end{tabular}

Pesq. agropec. bras., Brasília, v.44, n.5, p.478-486, maio 2009 
that might represent the three cycles simultaneously. It was further possible to remove two sites of the $13 \mathrm{key}$ locations initially chosen throughout the region, Anápolis (medium maturity cycle) and Luziânia (early maturity cycle), that could be represented, respectively, by Senador Canedo (second smallest mean distance in its stratum, in the medium maturity group) and Placas (second smallest mean distance in its stratum, in the early maturity group). As these two locations were already part of the previous list of key locations, the total number of test points chosen as priority for the final selection phases in the breeding program could be reduced from 18 to 11 locations: Buritis, Pamplona, Placas, Rio Verde, Senador Canedo, Chapadão do Céu, Iraí, Uberlândia, Uberaba, Planaltina, and Sacramento.

The results obtained in this study suggest that future soybean genotype trials could be cost-effectively conducted in a few representative sites selected from within each of the identified site groups. Recently, other papers have shown similar opportunity to different crops in different parts of the world, like Dehghani et al. (2009) with corn in Iran, Sanii et al. (2009) with rice in Africa, and Miranda et al. (2009) with popcorn in Brazil.

\section{Locations for genotype tests in the initial phases of selection}

The results shown in Tables 5, 6, 7, and 8 provide information related to the choosing of a key location for initial phases of the breeding program under study.

The winning genotypes with early maturity cycle were best classified in Rio Verde, Placas, and Cristalina (Table 5), which made these locations as putative key locations for the initial phases of selection. For the medium maturity winning genotypes, the outstanding locations were Mineiros, Placas, and Rio Verde (Table 6), which were also candidate key locations for initial phases. For the late maturity group (Table 7), the locations Chapadão do Céu, Mineiros, and Anápolis were identified as the ones that best classified the winning genotypes.

It was further observed that the genotypes with greater numbers of victories in the set of assessed

Table 4. Environmental strata and winning genotypes with their GE interaction scores (IPCA1), estimated by AMMI analysis, and the quadratic distances $\left(\mathrm{D}^{2}\right)$ between each location and the winning genotype of the respective stratum, for the late maturity group of soybean genotypes, in three assessment years(1).

\begin{tabular}{|c|c|c|c|c|c|c|c|}
\hline \multirow{2}{*}{$\begin{array}{l}\text { Environmental } \\
\text { strata }\end{array}$} & \multicolumn{2}{|c|}{2000} & \multicolumn{2}{|c|}{2001} & \multicolumn{2}{|c|}{2002} & \multirow[t]{2}{*}{$\overline{\mathrm{D}}^{2(2)}$} \\
\hline & IPCA1 & $\mathrm{D}^{2}$ & IPCA1 & $\mathrm{D}^{2}$ & IPCA1 & $\mathrm{D}^{2}$ & \\
\hline Rio Verde, GO & -5.22 & 24.50 & 1.68 & 7.73 & 0.69 & 5.34 & 12.52 \\
\hline Capinópolis, MG & -3.10 & 49.98 & 1.31 & 9.92 & -3.47 & 3.42 & 21.11 \\
\hline Anápolis, GO & -5.04 & 26.32 & 8.41 & 15.60 & 7.25 & 31.70 & 24.54 \\
\hline Mineiros, GO & 0.68 & 117.72 & 4.67 & 0.04 & -1.70 & 0.01 & 39.26 \\
\hline Senador Canedo, GO & -8.09 & 4.33 & 13.10 & 74.65 & -9.92 & 68.89 & 49.29 \\
\hline Lucas do Rio Verde, MT & Т 5.04 & 231.34 & 1.54 & 8.53 & -4.51 & 8.35 & 82.74 \\
\hline Chapadão do Céu, GO & 3.76 & 194.04 & 12.33 & 61.94 & -11.04 & 88.74 & 114.91 \\
\hline Conquista, MG & -3.05 & 50.69 & 16.43 & 143.28 & 12.30 & 193.77 & 129.25 \\
\hline Winning genotypes & \multicolumn{2}{|c|}{ BR96-11552 CE; IPCA1 $=-10.17$} & \multicolumn{2}{|c|}{ GOBR95-12203; IPCA1 $=4.46$} & \multicolumn{2}{|c|}{ BR97-11548; IPCA1 = -1.62 } & - \\
\hline Buritis, MG & 11.96 & 76.75 & -26.32 & 256.00 & 0.37 & 3.96 & 45.31 \\
\hline Luziânia, GO & 5.87 & 220.55 & -5.48 & 23.43 & 9.73 & 128.82 & 92.42 \\
\hline Winning genotypes & \multicolumn{2}{|c|}{ MSOY-8800 (T); IPCA1 = 20.72} & \multicolumn{2}{|c|}{ Uirapuru; IPCA1 = -10.32 } & \multicolumn{2}{|c|}{ BR97-11548; IPCA1 = -1.62 } & - \\
\hline Placas, BA & -9.03 & 1.30 & -3.03 & 53.14 & 5.75 & 54.32 & 36.25 \\
\hline Cristalina, GO & -6.44 & 13.91 & -23.35 & 169.78 & -2.87 & 1.56 & 61.75 \\
\hline Correntina, BA & -27.55 & 302.06 & -20.29 & 99.40 & 2.62 & 17.98 & 139.81 \\
\hline Winning genotypes & \multicolumn{2}{|c|}{ BR96-11552 CE; IPCA1 = -10.17 } & \multicolumn{2}{|c|}{ Uirapuru; IPCA1 = -10.32 } & \multicolumn{2}{|c|}{ BR97-11548; IPCA1 = -1.62 } & - \\
\hline Pamplona, DF & -3.58 & 43.43 & -4.11 & 38.56 & -21.05 & 53.93 & 45.31 \\
\hline Planaltina, GO & -3.71 & 41.73 & -25.18 & 220.82 & -24.56 & 17.70 & 92.42 \\
\hline Winning genotypes & \multicolumn{2}{|c|}{ BR96-11552 CE; IPCA1 = -10.17 } & \multicolumn{2}{|c|}{ Uirapuru; IPCA1 = -10.32 } & \multicolumn{2}{|c|}{ BR95-28822; IPCA1 = -28.39 } & - \\
\hline Iraí de Minas, MG & 40.88 & - & 17.06 & - & 18.69 & - & - \\
\hline Winning genotypes & \multicolumn{2}{|c|}{ MGBR95-20937 } & \multicolumn{2}{|c|}{ MGBR97-2762 } & \multicolumn{2}{|c|}{ GOBR97-08728 } & - \\
\hline Sacramento, MG & 10.13 & - & 19.59 & - & -0.08 & - & - \\
\hline Winning genotypes & \multicolumn{2}{|c|}{ MSOY-8800 (T) } & \multicolumn{2}{|c|}{ GOBR97-061004 } & \multicolumn{2}{|c|}{ BR97-11548 } & - \\
\hline Uberaba, MG & -3.45 & - & 11.65 & - & 36.29 & - & - \\
\hline Winning genotypes & \multicolumn{2}{|c|}{ BR96-11553 CE } & \multicolumn{2}{|c|}{ GOBR95-12203 } & \multicolumn{2}{|c|}{ GOBR97-08728 } & - \\
\hline
\end{tabular}


locations were, frequently, identified as promising genotypes in the locations defined here as putative key locations. For the early maturity group, among the genotypes with greater numbers of victories in each year, only MGBR97-2545 genotype, in 2002, was not a winner in one of the candidate locations (Rio Verde), where, however, it was placed second (Table 5). For the medium maturity group, only 'MSOY-8411', also in 2002, was not the winner in one of the candidate locations (Mineiros), but was placed third (Table 6).

Table 5. Ranks of the grain yield means for the soybean winning genotypes of the early maturity group, in each location ${ }^{(1)}$.

\begin{tabular}{|c|c|c|c|c|c|c|c|c|c|c|c|c|c|c|c|c|c|c|c|}
\hline $\begin{array}{l}\text { Winning } \\
\text { genotypes }\end{array}$ & $\begin{array}{c}\text { Number } \\
\text { of wins }\end{array}$ & Rver & Plac & Cris & Pamp & Lrve & Buri & Ubba & Luzi & Mine & Capi & Scan & Cceu & Anap & Sacr & Ubrl & Corr & Plan & Iraí \\
\hline & & & & & & & & & & 2000 & & & & & & & & & \\
\hline BR95-15305 CE & 4 & 2 & 2 & 2 & 1 & 2 & 2 & 6 & 2 & 2 & 1 & 2 & 2 & 3 & 1 & 1 & 2 & 4 & 6 \\
\hline BR95-7783 CE & 2 & 20 & 23 & 7 & 5 & 26 & 22 & 26 & 14 & 22 & 6 & 18 & 26 & 1 & 7 & 3 & 18 & 1 & 26 \\
\hline BR89-10744 CE & 10 & 1 & 1 & 1 & 3 & 1 & 1 & 2 & 1 & 1 & 2 & 1 & 1 & 4 & 2 & 4 & 1 & 7 & 2 \\
\hline BR96-019431 CE & 2 & 7 & 4 & 15 & 22 & 3 & 4 & 1 & 10 & 4 & 20 & 7 & 3 & 23 & 16 & 23 & 7 & 24 & 1 \\
\hline Year average & & 4.00 & 4.00 & 3.44 & 4.89 & 4.22 & 3.89 & 5.44 & 3.67 & 3.89 & 4.22 & 3.78 & 4.22 & 5.56 & 3.89 & 5.33 & 3.78 & 7.56 & 5.44 \\
\hline \multirow[t]{2}{*}{ Rank in the year } & & 9 & 8 & 1 & 13 & 12 & 5 & 16 & 2 & 6 & 10 & 4 & 11 & 17 & 7 & 14 & 3 & 18 & 15 \\
\hline & & & & & & & & & & 2001 & & & & & & & & & \\
\hline MG/BR95-964 & 10 & 1 & 1 & 1 & 1 & 1 & 1 & 1 & 1 & 2 & 2 & 2 & 6 & 3 & 4 & 1 & 2 & 1 & 14 \\
\hline BR97-09853 & 2 & 2 & 2 & 5 & 3 & 2 & 6 & 3 & 2 & 1 & 10 & 14 & 2 & 1 & 2 & 2 & 10 & 3 & 7 \\
\hline BRAS 97-8091 & 3 & 5 & 5 & 18 & 12 & 9 & 22 & 12 & 5 & 5 & 23 & 25 & 1 & 2 & 1 & 5 & 23 & 15 & 1 \\
\hline FT-2000 & 3 & 10 & 11 & 3 & 6 & 6 & 2 & 6 & 11 & 14 & 1 & 1 & 18 & 17 & 17 & 11 & 1 & 5 & 23 \\
\hline Year average & & 3.28 & 3.44 & 4.61 & 3.89 & 3.28 & 5.22 & 3.89 & 3.44 & 4.39 & 6.22 & 7.00 & 6.72 & 4.94 & 5.44 & 3.44 & 6.22 & 4.22 & 12.56 \\
\hline \multirow[t]{2}{*}{ Rank in the year } & & 1 & 4 & 10 & 6 & 2 & 12 & 7 & 3 & 9 & 15 & 17 & 16 & 11 & 13 & 5 & 14 & 8 & 18 \\
\hline & & & & & & & & & & 2002 & & & & & & & & & \\
\hline MGBR97-2545 & 10 & 2 & 1 & 1 & 1 & 5 & 3 & 3 & 1 & 1 & 2 & 1 & 3 & 1 & 1 & 1 & 9 & 9 & 1 \\
\hline GOBR96-014101 & 3 & 1 & 2 & 2 & 2 & 2 & 2 & 1 & 2 & 2 & 1 & 2 & 2 & 2 & 2 & 5 & 6 & 5 & 5 \\
\hline APIAKAS & 5 & 3 & 4 & 3 & 4 & 1 & 1 & 2 & 14 & 10 & 3 & 4 & 1 & 10 & 15 & 17 & 1 & 1 & 17 \\
\hline Year average & & 2.11 & 2.00 & 1.72 & 2.00 & 3.39 & 2.28 & 2.39 & 4.78 & 3.67 & 2.11 & 2.00 & 2.28 & 3.67 & 5.06 & 6.11 & 6.28 & 6.11 & 6.11 \\
\hline \multirow[t]{3}{*}{ Rank in the year } & & 5 & 2 & 1 & 3 & 10 & 7 & 9 & 13 & 11 & 6 & 4 & 8 & 12 & 14 & 15 & 18 & 16 & 17 \\
\hline & \multicolumn{19}{|c|}{ General average } \\
\hline & & 3.13 & 3.15 & 3.26 & 3.59 & 3.63 & 3.80 & 3.91 & 3.96 & 3.98 & 4.19 & 4.26 & 4.41 & 4.72 & 4.80 & 4.96 & 5.43 & 5.96 & 8.04 \\
\hline Final rank & & 1 & 2 & 3 & 4 & 5 & 6 & 7 & 8 & 9 & 10 & 11 & 12 & 13 & 14 & 15 & 16 & 17 & 18 \\
\hline
\end{tabular}

Table 6. Ranks of the grain yield means for the soybean winning genotypes of the medium maturity group, in each location $^{(1)}$.

\begin{tabular}{|c|c|c|c|c|c|c|c|c|c|c|c|c|c|c|c|c|c|c|c|}
\hline $\begin{array}{l}\text { Winning } \\
\text { genotypes }\end{array}$ & $\begin{array}{c}\text { Number } \\
\text { of wins }\end{array}$ & Mine & Plac & Rver & Pamp & Ubba & Capi & Scan & Lrve & Cris & Luzi & Buri & Plan & Corr & Sacr & Anap & Ubrl & Cceu & Iraí \\
\hline \multicolumn{20}{|c|}{2000} \\
\hline BR96-013721 MG & 2 & 20 & 9 & 20 & 20 & 7 & 20 & 8 & 3 & 17 & 7 & 24 & 23 & 20 & 6 & 20 & 1 & 1 & 2 \\
\hline BRAS95-30005 CE & 3 & 4 & 3 & 4 & 4 & 1 & 4 & 3 & 1 & 3 & 3 & 6 & 4 & 4 & 1 & 4 & 2 & 5 & 5 \\
\hline BR96-016119 MG & 1 & 26 & 26 & 26 & 26 & 26 & 26 & 26 & 21 & 26 & 26 & 26 & 26 & 26 & 25 & 26 & 6 & 2 & 1 \\
\hline BR92-2658 CE & 12 & 1 & 1 & 1 & 1 & 3 & 1 & 1 & 6 & 1 & 1 & 1 & 1 & 1 & 3 & 1 & 8 & 19 & 21 \\
\hline Year average & & 5.00 & 3.61 & 5.00 & 5.00 & 4.39 & 5.00 & 3.50 & 5.67 & 4.50 & 3.39 & 5.78 & 5.33 & 5.00 & 4.22 & 5.00 & 6.11 & 13.72 & 15.11 \\
\hline Rank in the year & & 7 & 3 & 8 & 11 & 5 & 9 & 2 & 14 & 6 & 1 & 15 & 13 & 12 & 4 & 10 & 16 & 17 & 18 \\
\hline \multicolumn{20}{|c|}{2001} \\
\hline CONQUISTA & 5 & 2 & 8 & 6 & 2 & 1 & 1 & 1 & 1 & 15 & 12 & 15 & 13 & 15 & 2 & 2 & 1 & 15 & 2 \\
\hline BR97-09894 & 3 & 15 & 20 & 20 & 15 & 9 & 2 & 2 & 5 & 27 & 21 & 28 & 26 & 28 & 1 & 1 & 2 & 28 & 1 \\
\hline BRAS97-0009 & 10 & 1 & 1 & 1 & 1 & 3 & 11 & 14 & 7 & 1 & 1 & 1 & 1 & 1 & 25 & 25 & 13 & 1 & 25 \\
\hline Year average & & 3.61 & 6.11 & 5.56 & 3.61 & 3.44 & 6.72 & 8.39 & 5.00 & 9.22 & 7.39 & 9.39 & 8.50 & 9.39 & 14.61 & 14.61 & 7.83 & 9.39 & 14.61 \\
\hline Rank in the year & & 2 & 6 & 5 & 3 & 1 & 7 & 10 & 4 & 12 & 8 & 13 & 11 & 14 & 16 & 17 & 9 & 15 & 18 \\
\hline \multicolumn{20}{|c|}{2002} \\
\hline GOBR97-15587 & 2 & 4 & 7 & 14 & 2 & 22 & 14 & 3 & 21 & 14 & 2 & 18 & 21 & 21 & 14 & 3 & 1 & 19 & 1 \\
\hline BRA97-6705 & 5 & 1 & 2 & 2 & 1 & 12 & 2 & 1 & 10 & 2 & 1 & 6 & 10 & 10 & 2 & 1 & 3 & 7 & 2 \\
\hline MSOY-8411 & 11 & 3 & 1 & 1 & 8 & 1 & 1 & 5 & 1 & 1 & 10 & 1 & 1 & 1 & 1 & 6 & 15 & 1 & 10 \\
\hline Year average & & 2.56 & 1.94 & 2.72 & 5.39 & 6.39 & 2.72 & 3.67 & 5.72 & 2.72 & 6.61 & 4.28 & 5.72 & 5.72 & 2.72 & 4.28 & 10.11 & 4.67 & 6.78 \\
\hline Rank in the year & & 2 & 1 & 3 & 11 & 15 & 4 & 7 & 12 & 5 & 16 & 8 & 13 & 14 & 6 & 9 & 18 & 10 & 17 \\
\hline \multicolumn{20}{|c|}{ General average } \\
\hline & & 3.72 & 3.89 & 4.43 & 4.67 & 4.74 & 4.81 & 5.19 & 5.46 & 5.48 & 5.80 & 6.48 & 6.52 & 6.70 & 7.19 & 7.96 & 8.02 & 9.26 & 12.17 \\
\hline Final rank & & 1 & 2 & 3 & 4 & 5 & 6 & 7 & 8 & 9 & 10 & 11 & 12 & 13 & 14 & 15 & 16 & 17 & 18 \\
\hline
\end{tabular}

Pesq. agropec. bras., Brasília, v.44, n.5, p.478-486, maio 2009 
Table 7. Ranks of the grain yield means for the soybean winning genotypes of the late maturity group, in each location ${ }^{(1)}$.

\begin{tabular}{|c|c|c|c|c|c|c|c|c|c|c|c|c|c|c|c|c|c|c|}
\hline $\begin{array}{l}\text { Winning } \\
\text { genotypes }\end{array}$ & $\begin{array}{c}\text { Number } \\
\text { of wins }\end{array}$ & Cceu & Mine & Anap & Capi & Lrve & Rver & Scan & Luzi & Conq & Plac & Sacr & Pamp & Ubba & Cris & Buri & Plan & Corr \\
\hline \multicolumn{19}{|c|}{2000} \\
\hline BR96-11552 CE & 11 & 2 & 1 & 1 & 1 & 2 & 1 & 1 & 3 & 1 & 1 & 5 & 1 & 1 & 1 & 5 & 1 & 2 \\
\hline BR95-1985 CE & 1 & 7 & 5 & 3 & 4 & 9 & 3 & 2 & 9 & 4 & 2 & 14 & 3 & 3 & 2 & 15 & 3 & 1 \\
\hline MSOY-8800 (T) & 5 & 1 & 2 & 4 & 3 & 1 & 4 & 7 & 1 & 3 & 7 & 1 & 4 & 4 & 6 & 1 & 4 & 21 \\
\hline MGBR95-20937MG & 1 & 4 & 6 & 12 & 11 & 3 & 12 & 20 & 2 & 11 & 22 & 2 & 12 & 12 & 15 & 2 & 12 & 25 \\
\hline Year average & & 2.11 & 1.78 & 2.56 & 2.28 & 2.17 & 2.56 & 3.78 & 2.72 & 2.28 & 3.89 & 4.22 & 2.56 & 2.56 & 3.22 & 4.28 & 2.56 & 8.50 \\
\hline Rank in the year & & 2 & 1 & 6 & 4 & 3 & 9 & 13 & 11 & 5 & 14 & 15 & 7 & 10 & 12 & 16 & 8 & 17 \\
\hline \multicolumn{19}{|c|}{2001} \\
\hline GOBR95-12203 & 8 & 1 & 1 & 1 & 1 & 1 & 1 & 1 & 2 & 2 & 2 & 4 & 2 & 1 & 13 & 13 & 13 & 12 \\
\hline MGBR97-2762 & 2 & 3 & 8 & 4 & 12 & 12 & 12 & 3 & 21 & 1 & 20 & 2 & 21 & 4 & 23 & 23 & 23 & 23 \\
\hline GOBR97-061004 & 1 & 5 & 23 & 12 & 24 & 24 & 24 & 5 & 26 & 4 & 25 & 1 & 26 & 6 & 26 & 26 & 26 & 26 \\
\hline UIRAPURU & 7 & 8 & 4 & 6 & 3 & 3 & 3 & 8 & 1 & 11 & 1 & 11 & 1 & 7 & 1 & 1 & 1 & 1 \\
\hline Year average & & 4.17 & 4.17 & 3.89 & 4.28 & 4.28 & 4.28 & 4.17 & 5.06 & 5.50 & 4.89 & 6.33 & 5.06 & 3.94 & 10.17 & 10.17 & 10.17 & 9.72 \\
\hline Rank in the year & & 4 & 3 & 1 & 6 & 7 & 8 & 5 & 10 & 12 & 9 & 13 & 11 & 2 & 15 & 16 & 17 & 14 \\
\hline \multicolumn{19}{|c|}{2002} \\
\hline GOBR97-08728 & 3 & 12 & 9 & 11 & 9 & 11 & 5 & 12 & 3 & 1 & 3 & 8 & 14 & 1 & 9 & 6 & 14 & 4 \\
\hline BR97-11548 & 13 & 1 & 1 & 1 & 1 & 1 & 1 & 1 & 1 & 2 & 1 & 1 & 7 & 10 & 1 & 1 & 7 & 1 \\
\hline BR95-28822 & 2 & 3 & 12 & 7 & 10 & 9 & 19 & 6 & 22 & 23 & 21 & 16 & 1 & 23 & 12 & 17 & 1 & 19 \\
\hline Year average & & 3.06 & 3.56 & 3.33 & 3.33 & 3.56 & 3.67 & 3.39 & 3.67 & 4.17 & 3.56 & 3.83 & 7.50 & 9.94 & 3.56 & 3.61 & 7.50 & 3.50 \\
\hline Rank in the year & & 1 & 8 & 3 & 2 & 6 & 11 & 4 & 12 & 14 & 7 & 13 & 15 & 17 & 9 & 10 & 16 & 5 \\
\hline \multicolumn{19}{|c|}{ General average } \\
\hline & & 3.11 & 3.17 & 3.26 & 3.30 & 3.33 & 3.50 & 3.78 & 3.81 & 3.98 & 4.11 & 4.80 & 5.04 & 5.48 & 5.65 & 6.02 & 6.74 & 7.24 \\
\hline Final rank & & 1 & 2 & 3 & 4 & 5 & 6 & 7 & 8 & 9 & 10 & 11 & 12 & 13 & 14 & 15 & 16 & 17 \\
\hline
\end{tabular}

${ }^{(1)}$ Locations are identified as: Chapadão do Céu (Cceu), Mineiros (Mine), Anápolis (Anap), Capinópolis (Capi), Lucas Do Rio Verde (Lrve), Rio Verde (Rver), Senador Canedo (Scan), Luziânia (Luzi), Conquista (Conq), Placas (Plac), Sacramento (Sacr), Pamplona (Pamp), Uberaba (Ubba), Cristalina (Cris), Buritis (Buri), Planaltina (Plan), and Correntina (Corr).

Table 8. Rank of the locations assessed, concerning their average capacity for highlight soybean winner genotypes, in the three maturity groups.

\begin{tabular}{lccrr}
\hline Location & \multicolumn{3}{c}{ Maturity cycle } & Mean \\
\cline { 2 - 4 } & Early & Medium & Late & \\
\hline Rio Verde, GO & 1 & 3 & 6 & 3.3 \\
Mineiros, GO & 9 & 1 & 2 & 4.0 \\
Placas, BA & 2 & 2 & 10 & 4.7 \\
Lucas do Rio Verde, MT & 5 & 8 & 5 & 6.0 \\
Capinópolis, MG & 10 & 6 & 4 & 6.7 \\
Pamplona, DF & 4 & 4 & 12 & 6.7 \\
Uberaba, MG & 7 & 5 & 13 & 8.3 \\
Senador Canedo, GO & 11 & 7 & 7 & 8.3 \\
Cristalina, GO & 3 & 9 & 14 & 8.7 \\
Luziânia, GO & 8 & 10 & 8 & 8.7 \\
Chapadão do Céu, GO & 12 & 17 & 1 & 10.0 \\
Conquista, MG & - & - & 10 & 10.0 \\
Anápolis, GO & 13 & 15 & 3 & 10.3 \\
Buritis, MG & 6 & 11 & 15 & 10.7 \\
Sacramento, MG & 14 & 14 & 11 & 13.0 \\
Planaltina, DF & 17 & 12 & 16 & 15.0 \\
Correntina, BA & 16 & 13 & 17 & 15.3 \\
Uberlândia, MG & 15 & 16 & - & 15.5 \\
Iraí de Minas, MG & 18 & 18 & 18 & 18.0 \\
\hline
\end{tabular}

For the late maturity group, only BR96-1152 did not win in Chapadão do Céu, in 2000, where it was placed second (Table 7). These results show the capacity of the chosen locations to preserve by selection most of the winning genotypes.
A general classification for the three maturity groups, covering the three years of the study, is shown in Table 8. It was verified that the locations Rio Verde, Mineiros, and Placas were the ones that ranked better (with lowest classification means) the winning genotype, taking into account the three cycles. It is interesting to observe that locations which ranked badly the winning genotypes in one cycle did also, generally, the same in the others (Sacramento, Planaltina, Correntina, Uberlândia, and Iraí). This tendency was also shown in those locations that ranked well the winning genotypes, such as Rio Verde, Mineiros and Placas. Among these, Mineiros location would be discarded according to the established criteria, because it was not elected as a key location for final assessment phases. Thus, the recommendation for developing the initial phases of the breeding program as headquarters would be Rio Verde or Placas. The option for one or another should consider additional criteria, such as administrative or operational facilities, which are relevant for the efficacy of breeding programs.

Finally, the method explained here to indicate key locations for the initial phases of selection has flexibility to indicate the location that best classifies a greater number of winners, instead of the location that best classifies the main winning genotype (first place in each location) 


\section{Conclusions}

1. It is possible to reduce the trial network assessed in this study from 18 to 11 key locations: Buritis, Chapadão do Céu, Iraí, Pamplona, Placas, Planaltina, Rio Verde, Sacramento, Senador Canedo, Uberaba, and Uberlândia.

2. Rio Verde or Placas should be indicated as location for developing the initial phases of the line selection process, in the present breeding program.

\section{Acknowledgements}

To Embrapa Cerrados and "Convênio Cerrados" for providing data; to professors José Branco de Miranda Filho, Heyder Diniz Silva, Edward Madureira Brasil and Lázaro José Chaves, for their help in the interpretation of the results.

\section{References}

CASANOVES, F.; BALDESSARI, J.; BALZARINI, M. Evaluation of multienvironment trials of peanut cultivars. Crop Science, v.45, p.18-26, 2005.

CROSSA, J. Statistical analyses of multilocation trials. Advances in Agronomy, v.44, p.55-85, 1990.

DEHGHANI, H.; EBADI, A.; YOUSEFI, A. Biplot analysis of genotype by environment interaction for barley yield in Iran. Agronomy Journal, v.98, p.388-393, 2006.

DEHGHANI, H.; SABAGHNIA, N.; MOGHADDAM, M. Interpretation of genotype-by-environment interaction for late maize hybrids' grain yield using a biplot method. Turkish Journal of Agriculture and Forestry, v.33, p.139-148, 2009.

GABRIEL, K.R. Least squares approximation of matrices by additive and multiplicative models. Journal of the Royal Statistical Society Series B - Methodological, v.40, p.186-196, 1978.

GABRIEL, K.R. The biplot graphic display of matrices with application to principal component analysis. Biometrika, v.58, p.453-467, 1971.

GAUCH JUNIOR, H.G. Statistical analysis of regional yield trials: AMMI analysis of factorial designs. Amsterdam: Elsevier, 1992. $278 \mathrm{p}$.

GAUCH JUNIOR, H.G. Statistical analysis of yield trials by AMMI and GGE. Crop Science, v.46, p.1488-1500, 2006.
GAUCH JUNIOR, H.G.; PIEPHO, H.P.; ANNICCHIARICO, P. Statistical analysis of yield trials by AMMI and GGE: further considerations. Crop Science, v.48, p.866-889, 2008.

GAUCH JUNIOR, H.G.; ZOBEL, R.W. Identifying mega-environments and targeting genotypes. Crop Science, v.37, p.311-326, 1997.

IBGE. Base estatcart de informações municipais 2007. Rio de Janeiro: IBGE, 2008. 1 CD-ROM.

IBGE. Levantamento sistemático da produção agrícola. Rio de Janeiro: IBGE, 2009. v.21. p.1-79.

INTERNATIONAL MAIZE AND WHEAT IMPROVEMENT CENTER. CIMMYT toward the $\mathbf{2 1}^{\text {th }}$ century: CIMMYT'S strategy. El Batan: CIMMYT, 1989.

MIRANDA, G.V.; SOUZA, L.V. de; GUIMARÃES， L.J.M.; NAMORATO, H.; OLIVEIRA, L.R.; SOARES, M.O. Multivariate analyses of genotype $\mathrm{x}$ environment interaction of popcorn. Pesquisa Agropecuária Brasileira, v.44, p.45-50, 2009.

PACHECO, R.M. Estratificação de ambientes em cerrados do Brasil Central para fins de seleção e recomendação de cultivares de soja. 2004. 170p. Tese (Doutorado) Universidade Federal de Goiás, Goiânia.

PUTTO, W.; PATANOTHAI, A.; JOGLOY, S.; HOOGENBOOM, G. Determination of mega-environments for peanut breeding using the CSM-CROPGRO-peanut model. Crop Science, v.48, p.973-982, 2008.

ROOZEBOOM, K.L.; SCHAPAUGH, W.T.; TUINSTRA, M.R.; VANDERLIP, R.L.; MILLIKEN, G.A. Testing wheat in variable environments: genotype, environment, interaction effects, and grouping test locations. Crop Science, v.48, p.317-330, 2008.

SANNI, K.A.; ARIYO, O.J.; OJO, D.K.; GREGORIO, G.; SOMADO, E.A.; SANCHEZ, I.; SIE, M.; FUTAKUCHI, K.; OGUNBAYO, S.A.; GUEI, R.G.; WOPEREIS, M.C.S. Additive main effects and multiplicative interactions analysis of grain yield performances in rice genotypes across environments. Asian Journal of Plant Sciences, v.8, p.48-53, 2009.

YAN, W.K.; HUNT, L.A.; SHENG, Q.L.; SZLAVNICS, Z. Cultivar evaluation and mega-environment investigation based on the GGE biplot. Crop Science, v.40, p.597-605, 2000

YAN, W.K.; KANG, M.S.; MA, B.L.; WOODS, S.; CORNELIUS, P.L. GGE biplot vs. AMMI analysis of genotype-by-environment data. Crop Science, v.47, p.643-655, 2007.

YAN, W.K.; TINKER, N.A. An integrated biplot analysis system for displaying, interpreting, and exploring genotype $\mathrm{x}$ environment interaction. Crop Science, v.45, p.1004-1016, 2005.

ZOBEL, R.W.; WRIGHT, M.J.; GAUCH, H.G. Statistical analysis of a yield trial. Agronomy Journal, v.80, p.388-393, 1988.

Received on Dezember 3, 2008 and accepted on April 30, 2009

Pesq. agropec. bras., Brasília, v.44, n.5, p.478-486, maio 2009 